\title{
Nursing Education in a Curriculum Oriented of Competence: A Systematic Review
}

\author{
Luciene Rodrigues Barbosa*, Luciane Lúcio Pereira \\ University Guarulhos, Guarulhos, Brazil \\ Email: " lucienerodriguesbarbosa@gmail.com
}

Received 5 May 2015; accepted 9 October 2015; published 13 October 2015

Copyright (C) 2015 by authors and Scientific Research Publishing Inc.

This work is licensed under the Creative Commons Attribution International License (CC BY).

http://creativecommons.org/licenses/by/4.0/

(c) () Open Access

\begin{abstract}
This systematic review aims to identify scientific publications addressing the teaching of competence management for undergraduate students of nursing. A systematic review was conducted using PubMed, LILASC, MEDLINE and the PRISMA guidelines (Preferred Reporting Items for Systematic Reviews and Meta-Analyses), using the following keywords: competence management, professional skills, education and nursing. The search resulted in 77 articles that were screened by title and abstract. These 11 articles were analyzed. In this research observed it most articles $63.6 \%$ articles among those selected address competence management as a tool to be developed by the students during their academic education and $36.4 \%$ discussed the development of a political-pedagogical. We expect that the subject identified in this study may contribute to the development of critical/reflexive thinking and attitudes in nursing.
\end{abstract}

\section{Keywords}

Professional Skills, Undergraduate Nursing Education, Competence Nursing, Curriculum Development

\section{Introduction}

Changes in the economic scenario have given rise to the transformation of the labor process, and led organizations to seek a new employee profile. The organizations assume that their employees, within the professional scope, are able to develop their professional activities with competence.

The search for quality and excellence of services, brought changes on management models and, consequently, the way of manage peoples change too. Reports that the recognition of roles professional interpret in an institution, leave the most appreciation of human deed how way to obtain of institutional object.

The transforms observed in world of work, the change of paradigm and the new profile required for the pro-

\footnotetext{
${ }^{*}$ Corresponding author.
} 
fessionals, were also observed in the health services, specifically on Nursing while profession and the education of nurse (Karadağ et al., 2015; Scott Tilley, 2008).

In order to become a professional who is able to develop activities of curative and preventive health, its formation needs to be consolidated in Curriculum Guidelines and reflect on Politics Pedagogical Project that is constantly discussed by the people who are interested in the topic (Brasil, 2007).

Together with concern on labor market was structured an education system based in professional competence. The implementation of this education system demonstrates that educational politics seek to keep pace of labor market and offer, in its educational content, themes that are necessary to professional formation.

Specifically in nursing, it is observed that the Institutions of Higher Education, by methodology and contents used, or by describing formation profile, have looking for adapting the education offered to requirements established by labor world.

Therefore, the teaching nursing process is structured on development of competences, keeps track of the requirements on labor market, allows critical, reflective and professional formation and is able to make decisions individually (Fernandes \& Fonseca, 2011; Ličen \& Plazar, 2015). To be competent, it can adapt the knowledge in different situations of work and make decisions from information analyzed and evaluated.

In learning context in an approach of competence, individual makes own knows in an interaction that provides learning to learn. The way of making decisions and solving problems is proposed on learning environment (Fontes, Ferreira \& Araújo, 2010). So, the university is the responsible for education/development of competences, since once formed, the professional goes to labor market with the knowledge of university (Preheim, Armstrong, \& Barton, 2009; Barbosa \& Pereira, 2014).

The National Curriculum Guidelines of Graduation Nursing Course (DCNs/ENF) yet feature that students of the nursing course must develop general competences: health attention, decision, communication, leadership, permanent education and management (Brasil, 2007) when they finish graduation.

Although educational institutions are seeking to implement, through their syllabus, a new approach matching the proposed Curriculum Guidelines, this topic is addressed during the classes as something complicated, and sometimes may be considered as an arduous process.

This review study is aimed at discussing the teaching of professional skills for students of undergraduate nursing courses (Clarke \& Horton, 2001; Mendes, Pereira, \& Galvão, 2008). Its objective identifies scientific publications addressing the teaching of competence management for undergraduate students of nursing.

\section{Methods}

This is an exploratory systematic review study performed through critical analysis of articles. A planned thorough review aims to summarize the original research highlighting its relevant issues. It uses a clear method to identify, select and describe the studies quality, data collection and analysis (Mendes, Karina dal Sasso et al., 2008).

To start the study, the following guiding question was made: "What has scientific literature presented on the teaching of professional skills?”

The search and selection of open-access indexed scientific articles were conducted in national and international databases, as follows: PubMed (Public Medline), LILACS (Latina-American and Caribean System on Health Sciences Information) and MEDLINE (Medical Literature Analysis and Retrieval System Online). The search was focused on articles published in January 2008 till the final search that was conducted on June 2015.

\subsection{Guidelines Systematic Review}

Assessment of the scientific articles it was used PRISMA guidelines for methodology (Moher, Liberati, \& Tetzlaff, 2009). PRISMA is the often used methodology in systematic reviews for enhancing the clarity the quality of the systematic review (Fleming, Koletsi, \& Pandis, 2014).

\subsection{Identification and Screening}

To select the articles, inclusion and exclusion criteria were established and a thorough analysis of the articles quality was performed to ensure the reliability of selected literature, thus allowing increasing the study accuracy. 


\subsection{Eligibility}

The following Descriptors Health Sciences (DeCS) and Medical Subject Headings (MeSH) descriptors were established to check the quality of scientific publications. As a strategy to gather the articles, the first descriptor was crossed with the second, and subsequently, the descriptors mentioned earlier were crossed with the third one.

The selected articles were analyzed by two reviewers who judiciously and independently read the resumo/ resumen/abstract of the relevant materials in order to identify articles fulfilling the inclusion criteria established for this review. Table 1 provides an overview of the literature search.

\section{Results}

With respect to selected articles, the articles were identified at the first crossing, with 39 in LILACS, 18 in MEDLINE and 20 in PubMed. Thus, a total of 77 articles were identified.

All articles that did not address the proposed theme, whose full version was not available and that were repeated in more than one database were excluded from this review $n=66$, thereby forming a sample of $(n=11)$ articles. The articles selection flow is shown in Figure 1.

With regard to characterization of selected articles, Chart 1 shows the study distribution by authors, objectives, data collection techniques, final considerations, and journal identification. Overall, it should be noted that the publications that address the teaching of professional skills are predominantly found in nursing journals (72.7\%),

Table 1. Type styles literature search.

Literature search

\section{PubMed, Lilasc and Medline}

Search criteria

- $\quad$ Articles published 2008 till December 2015.

- English language.

- MeSH terms and DeCS: professional skills, competence nursing, education and nursing.

\section{Selection for inclusion based on title}

Competece nursing major area of interest + keyword

- Education

- Student

- University

- Students of nursing

- Professional skills

Selection for inclusion based on abstract and eligibility phase

Inclusion:

- Explanatory articles for the relationship between professional skills and nursing.

- Available online for free and full texts.

- Focused on the study object.

\section{Exclusion:}

- Describing only concept of professional skills.

- Opinion articles, letter to editor, dissertations and theses.

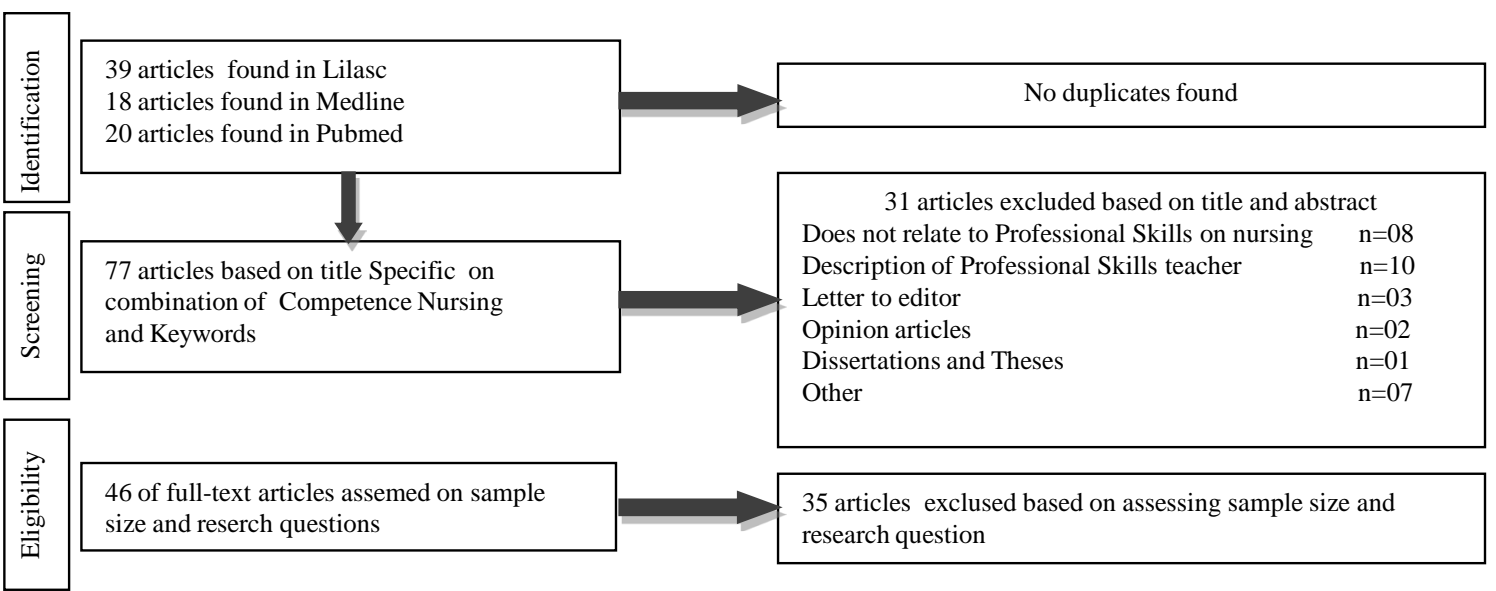

11 Full Reading and Selection of Articles

Figure 1. Flow diagram of article selction for analysis. 
followed by education nursing journals (27.3\%). Selected articles showed that researches with this theme were mostly conducted in Brazil (54.5\%).

A total of $10.0 \%$ of the selected studies are original articles that used the following data collection techniques: Experience report (9.1\%), questionnaire (27.3\%), focal group (27.3\%) and documentary source (27.3\%). In relation to data collection, one can still observe that $9.1 \%$ of the articles used three different techniques to obtain the necessary information. Table 2 provides an overview of the the main outcomes per included study.

Table 2. Characterization of selected articles for analysis.

\begin{tabular}{|c|c|c|c|c|c|}
\hline Reference & $\begin{array}{l}\text { Data collection } \\
\text { techniques }\end{array}$ & Objectives & Main outcome & Journal & Country \\
\hline $\begin{array}{l}\text { (Pijl-Zieber, } \\
\text { Barton, Konkin, } \\
\text { Awosoga, \& } \\
\text { Caine, 2015) }\end{array}$ & $\begin{array}{l}\text { Documentary } \\
\text { source }\end{array}$ & $\begin{array}{l}\text { Critique the use of } \\
\text { competence } \\
\text { frameworks in } \\
\text { nursing education. }\end{array}$ & $\begin{array}{l}\text { The language of competence } \\
\text { is widely utilized in both the } \\
\text { regulation of nursing practice } \\
\text { and curricular design in nursing } \\
\text { education. The notion of } \\
\text { competence defines what it } \\
\text { means to be a professional, } \\
\text { although it is not the only way } \\
\text { of describing nursing practice. }\end{array}$ & $\begin{array}{l}\text { Nurse } \\
\text { Education } \\
\text { Today }\end{array}$ & Canada \\
\hline $\begin{array}{l}\text { (Fontes et al., } \\
\text { 2010) }\end{array}$ & $\begin{array}{l}\text { Likert } \\
\text { questionnaire }\end{array}$ & $\begin{array}{l}\text { To investigate the skills, } \\
\text { knowledge and abilities of } \\
\text { undergraduates to apply } \\
\text { the nursing process. }\end{array}$ & $\begin{array}{l}\text { It is concluded that it is necessary } \\
\text { to have skills, knowledge, and } \\
\text { abilities to apply the steps of the } \\
\text { nursing process. }\end{array}$ & $\begin{array}{l}\text { Rev. Rene. } \\
\text { Fortaleza. }\end{array}$ & Brazil \\
\hline $\begin{array}{l}\text { (Keogh, Fourie, } \\
\text { Watson, \& } \\
\text { Gay, 2015) }\end{array}$ & Focal group & $\begin{array}{l}\text { Involve stakeholders } \\
\text { from the health care } \\
\text { sector in developing } \\
\text { a new curriculum, } \\
\text { and after implementing } \\
\text { the new curriculum } \\
\text { evaluated the process. }\end{array}$ & $\begin{array}{l}\text { The curriculum development } \\
\text { process could be a painful } \\
\text { process for all concerned, but a } \\
\text { strong leadership could cement a } \\
\text { feeling of “collegiality” between } \\
\text { stakeholders and teaching staff. }\end{array}$ & $\begin{array}{l}\text { Nurse } \\
\text { Education } \\
\text { Today }\end{array}$ & Canada \\
\hline $\begin{array}{l}\text { (Tronchin } \\
\text { \& Melleiro, } \\
\text { 2008) }\end{array}$ & $\begin{array}{l}\text { Experience } \\
\text { report }\end{array}$ & $\begin{array}{l}\text { Has the purpose of } \\
\text { reporting the following } \\
\text { prognosticators: } \\
\text { planning, decision-taking, } \\
\text { supervision, human } \\
\text { resource management, } \\
\text { material resource } \\
\text { management, information. }\end{array}$ & $\begin{array}{l}\text { The student evaluation has } \\
\text { promoted responsibility and the } \\
\text { commitment of student, seeking } \\
\text { solutions to face the problems of } \\
\text { teaching and learning, becoming } \\
\text { in a participatory process of action- } \\
\text { reflection-action, aimed at } \\
\text { transforming the construction of } \\
\text { knowledge. }\end{array}$ & $\begin{array}{l}\text { Acta Paul } \\
\text { Enferm }\end{array}$ & Brazil \\
\hline $\begin{array}{l}\text { (Farrand, } \\
\text { McMullan, } \\
\text { Jowett, \& } \\
\text { Humphreys, } \\
\text { 2015) }\end{array}$ & $\begin{array}{l}\text { Self-administered } \\
\text { questionnaire }\end{array}$ & $\begin{array}{l}\text { Examine whether the } \\
\text { implementation of the } \\
\text { competency recommendations } \\
\text { has led to improvements in } \\
\text { the confidence of nursing } \\
\text { students in their clinical skills. }\end{array}$ & $\begin{array}{l}\text { The positive effect that the } \\
\text { competency recommendations } \\
\text { had upon levels of confidence in } \\
\text { nursing practice. The students } \\
\text { studying the competency } \\
\text { curriculum have higher levels of } \\
\text { confidence in all areas of their } \\
\text { practice targeted by the competency. }\end{array}$ & $\begin{array}{l}\text { Nurse } \\
\text { Education } \\
\text { Today }\end{array}$ & Canada \\
\hline $\begin{array}{l}\text { (Resck \& } \\
\text { Gomes, } \\
\text { 2008) }\end{array}$ & Focal group & $\begin{array}{l}\text { To analyze the requirements } \\
\text { and expectations arising from } \\
\text { the managerial practices setting } \\
\text { against the Pedagogical Project } \\
\text { and the strategies favorable or } \\
\text { unfavorable to transformative } \\
\text { praxis. }\end{array}$ & $\begin{array}{l}\text { Nursing education and praxis must } \\
\text { go through the working processes in } \\
\text { the scope of care, management, } \\
\text { education, and scientific research, } \\
\text { building paths for the development of } \\
\text { skills, with greater teaching-service } \\
\text { interaction, according to the current } \\
\text { National Curriculum Guidelines. }\end{array}$ & $\begin{array}{l}\text { Rev } \\
\text { Latino-Am } \\
\text { Enferm }\end{array}$ & Brazil \\
\hline $\begin{array}{l}\text { (Lourenção } \\
\text { \& Benito, } \\
\text { 2009) }\end{array}$ & $\begin{array}{l}\text { Documentary } \\
\text { source }\end{array}$ & $\begin{array}{l}\text { To identify the integration of } \\
\text { managerial skills in nursing } \\
\text { education. }\end{array}$ & $\begin{array}{l}\text { This study enabled the reflection on } \\
\text { the responsibility of educating } \\
\text { competent professionals and make } \\
\text { them enter the labor market to } \\
\text { perform health management actions. }\end{array}$ & $\begin{array}{l}\text { Rev Bras } \\
\text { Enferm }\end{array}$ & Brazil \\
\hline
\end{tabular}


Continued

\begin{tabular}{lll}
\hline & $\begin{array}{l}\text { To describe and analyze how } \\
\text { the configuration of professional }\end{array}$ \\
$\begin{array}{l}\text { (Dias \& } \\
\text { Paiva, }\end{array}$ & $\begin{array}{l}\text { Documentary } \\
\text { source, direct } \\
\text { observation and } \\
\text { a questionnaire }\end{array}$ & $\begin{array}{l}\text { and managerial skills of nursing } \\
\text { students varied before and after } \\
\text { they attended two management } \\
\text { subjects in the nursing course. }\end{array}$
\end{tabular}

$\begin{array}{ll}\text { (Benito \& } & \text { Documentary } \\ \text { Finato, } & \text { source } \\ \text { 2010) } & \end{array}$

The need to improve pedagogical practices developed at Higher Education Institutions related to that role was observed, as well as the roles of coordinator and director, in view of the (small) changes perceived by students about such roles.

The registers of the Pedagogical Project of this Course, presents a predominance of the dimension knowledge, over the dimensions ability and attitude, showing us that the contents does not reflect yet on the agreement of the Direction and Base Law (Lei de Diretrizes e Bases) praised by the Health department and the Ministry of Education for the nurse formation.

The training and counseling program had a positive influence on the professional attitudes of nursing students.
Rev. Min. Brazil Enferm

Rev. Eletr. Brazil
Enf.

Journal of professional Philadelphia nursing

Validate the technical skills of nurses in order to provide subsidies for creation of (Chaves
et al., 2010) Focal group nurse course curriculums for the Nursing School of Federal training and counseling on nursing students' professional attitudes. University of Minas Gerais, Brazil.

A competency-based training, student will be better qualified to act in harmony with the demands of society and the market. The Developing Curriculum methodology has allowed the collective participation of teachers, students and nurses of services in the construction of the Educational Project integrating education, work and school.

Professional skills in the development of a political-pedagogical project were the study object in most articles, and are present in 07 (63.6\%). Further, 04 (36.4\%) articles among those selected address competence management as a tool to be developed by the students during their academic education as a means of ensuring their professional performance in the nursing assistance and/or management area.

\section{Discussion}

Most studies on the teaching of professional skills found that due to the changes occurring in the labor market and healthcare sector this theme has been constantly discussed by teachers in undergraduate nursing course both in the preparation of the Political Pedagogical Project (PPP) and Curriculum education as a tool developed during the student education (Preheim et al., 2009; Resck \& Gomes, 2008). However, when analyzing the results shown in Table 1 on the scientific publications addressing professional skills, it can be noticed that teachers are more focused on developing the PPP in order to structure his theory syllabus, reinforcing the importance of developing in classroom the skills required by the Curriculum Guidelines for Undergraduate Nursing Course. Therefore, the use of professional skills as a tool developed during the student education still proves to be undervalued by teachers.

An interaction between these two views on the use of professional skills seems to be something still slightly distant from teaching reality, becoming a bureaucratic discussion where professional growth is still in the background. However, the articles show that in general teachers have tried to develop this theme both in their theoretical classes and practical experiences (Pijl-Zieber et al., 2015).

But it was found that many students still have difficulty in developing in practice the theoretical concepts taught (Mendes, Pereira, \& Galvão, 2008). Thus, it can be undoubtedly stated that there is a need to enhance the pedagogical practices of Higher Education Institutions so that abilities and skills be developed in these undergraduates.

For teachers, it is still somewhat complex to make undergraduates understand the teaching of professional skills; they realize the importance and responsibility of teaching this subject (Preheim et al., 2009). The difficul- 
ties and uncertainties felt by teachers at the time of teaching the skills that, at first, are shown to be something subjective may interfere with the student's teaching-learning process. This may represent a strong impact on the development of the nurse new professional profile expected by organizations in the healthcare sector. Thus, it is possible to understand why the discussion on this topic has been increasingly focusing on the preparation of PPP instead of being focused on student learning.

It is important to emphasize that teachers consider themselves as a mediating element in the teaching process, and believe that in general undergraduates can absorb the contents proposed in the amendments of curricular subjects (Tai \& Chung, 2008). Teachers believe that they are facilitators of the understanding of professional skills for students, preparing them to responsibly and efficiently perform their management activities in organizations.

Another important feature to be mentioned is that teachers claim that the undergraduates understand the significance of teaching general skills (Brasil, 2007; Fontes et al., 2010; Tanji \& de Oliveira Viana, 2012), and point out its relevance to improve their professional performance in organizations. This fact is relevant considering the conditions under which the teaching of professional skills have been developed at Higher Education Institutions: on the one hand, there are the teachers who express their difficulty in communicating to students something that seems to be subjective, and showing their high level of interest in make use of the skills directed to a more bureaucratic aspect; on the other hand, there are the organizations that require competent professionals to perform their tasks, thus adding economic value to the company and assuring its competitive advantage.

\section{Conclusion}

Through this critical and reflexive analysis, it was possible to develop a new perspective on the teachers and students point of view on teaching professional skills and comparing it with theoretical references on the skills that should be developed during the teaching-learning process, expanding the perception as to how they should be developed to cause changes in the nurse professional profile.

This view ends up weakening the teaching of managerial issues during academic education and harming the student not to develop its potential as a possible manager of his team. This problem results from a student's lack of knowledge about the importance of managerial skills, human resource management and care.

We do not have the purpose of exhausting all discussions on this theme, considering how complex the teaching of skills is. But it is believed that it is important to conduct discussions in education, society and nursing on professional skills developed on the nurse, and the challenges faced by teachers when teaching this theme.

The results allow us to claim that it is necessary to develop critical and reflexive thinking and attitudes to allow us to rethink about teaching practices, enabling a better interaction between the proposed Political Pedagogical Project and experience in the classroom.

\section{References}

Barbosa, L. R. (2015). Professional Competences and the Formation Process in Nursing: A Integrative Review. Journal of Nursing UFPE on Line, 9, 9393-9398. http://doi.org.10.5205/reuol.6812-75590-1-ED.0908sup201508

Barbosa, L. R., \& Pereira, L.P. (2014). The Teaching of Managerial Skills in the Perception of Teachers of Nursin Courses. Journal Nursing UFPE on Line, 8, 784-786. http://doi.org.10.5205/reuol.5149-42141-1-SM.0803201439

Benito, G. A. V., \& Finato, P. C. (2010). Managemental Abilities in the Formation of the Nurse: Documentary Analysis of a Pedagogical Project of Course. Revista Eletrônica de Enfermagem, 12, 140-149.

Brasil (2007). Ministério da Saúde. Portaria GM/MS n.1.996, de 20 de agosto de 2007. Dispõe sobre as diretrizes para a implementação da Política Nacional de Educação Permanente em Saúde e dá outras providências.

Chaves, M. M., Menezes Brito, M. J., Cozer Montenegro, L., \& Alves, M. (2010). Competencias profesionales de los enfermeros: El método developing a curriculum como posibilidad para elaborar un proyecto pedagógico. Enfermería Global, 18, 1-18. http://doi.org/10.4321/S1695-61412010000100012

Clarke, M., \& Hortona R. (2001). Bringing It All Together: Lancet-Cochrane Collaborate on Systematic Reviews. Lancet, 357, 1728. http://dx.doi.org/10.1016/s0140-6736(00)04934-5

Dias, H. C. V. B., \& Paiva, K. C. M. de (2009). Formação de Competências Gerenciais a partir de disciplinas de gestão no curso de Enfermagem: Percepções de alunos de uma universidade privada. Revista Mineira de Enfermagem, 13, 474-484.

Farrand, P., McMullan, M., Jowett, R., \& Humphreys, A. (2015). Implementing Competency Recommendations into PreRegistration Nursing Curricula: Effects upon Levels of Confidence in Clinical Skills. Nurse Education Today, 26, 97-103. 
http://dx.doi.org/10.1016/j.nedt.2005.06.002

Fernandes, M., Durão, J. B. F., \& Fonseca, A. M. L. P. (2011). Competency-Based to Nursing Education: Literature Review. Revista de Enfermagem UFPE on Line, 5, 472-480. http://dx.doi.org/10.5205/reuol.1718-11976-1-LE.05spe201121

Fleming, P. S., Koletsi, D., \& Pandis, N. (2014). Blinded by PRISMA: Are Systematic Reviewers Focusing on PRISMA and Ignoring Other Guidelines? PLOS ONE, 9. http://dx.doi.org/10.1371/journal.pone.0096407

Fontes, W., Ferreira, O., \& Araújo, J. D. C. P. L. (2010). Competences for the Application of the Nursing Process: SelfEvaluation of the Students That Are Completing the Requirements for the Unde. Journal of Northeastern Nursing Network, 11, 86-94.

Karadağ, A., Hisar, F., Göçmen Baykara, Z., Çalışkan, N., Karabulut, H., \& Öztürk, D. (2015). A Longitudınal Study on the Effect of Tailored Training and Counseling on the Professional Attitude of Nursing Students. Journal of Professional Nursing, 31, 262-270. http://dx.doi.org/10.1016/j.profnurs.2014.10.004

Keogh, J. J., Fourie, W. J., Watson, S., \& Gay, H. (2015). Involving the Stakeholders in the Curriculum Process: A Recipe for Success? Nurse Education Today, 30, 37-43. http://dx.doi.org/10.1016/j.nedt.2009.05.017

Ličen, S., \& Plazar, N. (2015). Identification of Nursing Competency Assessment Tools as Possibility of Their Use in Nursing Education in Slovenia-A Systematic Literature Review. Nurse Education Today, 35, 602-608. http://dx.doi.org/10.1016/j.nedt.2014.12.023

Lourenção, D. C. D. A., \& Benito, G. A. V. (2009). Competências gerenciais na formação do enfermeir. Revista Brasileira de Enfermagem, 63, 91-97.

Mendes, K. D. S., de Campos Pereira Silveira, R. C., \& Galvão, C. M. (2008). Revisão integrativa: Método de pesquisa para a incorporação de evidências na saúde e na Enfermagem. Texto \& Contexto—Enfermagem, 17, 758-764. http://dx.doi.org/10.1590/S0104-07072008000400018

Moher, D., Liberati, A., Tetzlaff, J., \& Altman, D. G. (2009). Preferred Reporting Items for Systematic Reviews and Meta Analyses: The Prisma Statement. PLoS Medicine, 6, e1000097. http://dx.doi.org/10.1371/journal.pmed.1000097

Pijl-Zieber, E. M., Barton, S., Konkin, J., Awosoga, O., \& Caine, V. (2015). Competence and Competency-Based Nursing Education: Finding Our Way through the Issues. Nurse Education Today, 34, 676-678. http://dx.doi.org/10.1016/j.nedt.2013.09.007

Preheim, G. J., Armstrong, G. E., \& Barton, A. J. (2009). The New Fundamentals in Nursing: Introducing Beginning Quality and Safety Education for Nurses' Competencies. The Journal of Nursing Education, 48, 694-697. http://dx.doi.org/10.3928/01484834-20091113-10

Resck, Z. M. R., \& Gomes, E. L. R. (2008). Background and Managerial Practice of Nurses: Paths for Transforming Praxis. Revista Latino-Americana de Enfermagem, 16, 71-77. http://dx.doi.org/10.1590/s0104-11692008000100012

Scott Tilley, D. D. (2008). Competency in Nursing: A Concept Analysis. Journal of Continuing Education in Nursing, 39, 58-64. http://dx.doi.org/10.3928/00220124-20080201-12

Tai, C.-Y., \& Chung, U.-L. (2008). The Development of a Competency-Based Group Health Teaching Performance Examination Model for BSN Graduates. The Journal of Nursing Research, 16, 275-285. http://dx.doi.org/10.1097/01.JNR.0000387315.05139.e9

Tanji, S., \& de Oliveira Viana, L. (2012). Continuing Education Subsidizing the Competence of Teachers of Graduate Nursing Course. Journal of Nursing UFPE, 6, 2065-2070.

Tronchin, D. M. R., Gonçalves, V. L. M., Leite, M. M. J., \& Melleiro, M. M. (2008). Instrumento de avaliação do aluno com base nas competências gerenciais do enfermeiro. Acta Paulista de Enfermagem, 21, 356-360.

http://dx.doi.org/10.1590/S0103-21002008000200020 